\title{
Four Years of Foetal Autopsies in A Peripheral Teaching Hospital: A Retrospective Analysis
}

\author{
Priya Subashchandrabose, Jayaganesh Parthasarathy* and Chitra Srinivasan \\ Department of Pathology, Saveetha Medical College, Chennai, India
}

\begin{abstract}
Background: The aim of our study was to assess the prevalent causes of foetal demise in our region, so as to facilitate necessary prenatal measures to reduce the Intra uterine deaths.

Methods: A retrospective study on 28 foetuses, received in the Department of Pathology, either because of intra uterine death or those which were medically terminated for various abnormal prenatal findings, for a period of 4 years from November 2011 to November 2015 . Autopsy report findings including full external examination, anthropometric measurements, gross, microscopic details of different organs including placenta and ultrasound reports were analysed.

Results: Total number of foetal autopsies was twenty eight. Most prevalent cause of death was congenital anomalies (39.3\%) followed by placental insufficiency (17.8\%) and umbilical cord anomaly (10.7\%). The most frequent multiple system anomalies were central nervous system defect and musculoskeletal system malformations. Foetal autopsy provided additional findings in 8 cases $(28.57 \%)$.

Conclusion: Foetal autopsy is a vital procedure in confirming the cause of foetal death. It also provides additional findings not identified through prenatal ultrasound. It provides the treating clinician and parents with very crucial information on implications for future pregnancies.
\end{abstract}

Keywords: Congenital Anomalies, Foetal Autopsy, Intra Uterine Death, Placental Abnormalities, Prenatal Diagnosis.

\section{Introduction}

Foetal autopsy is very valuable because it gives the parents, the cause for the death of their baby. Foetal death is classified as early (less than 22 weeks of gestational age), intermediate ( $22-27$ weeks of gestational age) and late (greater than 28 weeks of gestational age). The early deaths are referred to as abortions and the late and intermediate deaths are termed together as Intra uterine deaths (IUD) or still births. ${ }^{[1]}$ Congenital anomalies are an important cause of mortality in developing countries. Improvement in prenatal care can reduce the incidence to substantial amount. ${ }^{[2]}$ Genetic disorders or obstetric conditions that may cause recurrent threat to future pregnancies can be recognized. [3] IUD contributes substantially to perinatal mortality thus proving to be a good indicator of quality of antenatal care provided and also to assess the amount of pregnancy loss. ${ }^{[1]}$ The main objectives of the foetal autopsy include identification the gestational age and congenital abnormalities, document growth and development, assess and establish the cause of death and probable risk of recurrence. ${ }^{[4]}$ Our study was hence performed to identify the prevalent causes of IUD on foetal autopsies in our region, categorise them based on causes and thus help in taking essential steps to reduce the IUD by improvising the prenatal care.

\section{Materials and Methods}

After obtaining the institutional ethics committee, this retrospective study on 28 foetal autopsies performed in the department of Pathology, Saveetha Medical College, over a period of three years from November 2012 to November 2015 was performed. The cases, for which all the autopsy data were available, were included in the study. Macerated and autolyzed foetuses were excluded from the study. All the details in autopsy reports including gestational age, sex of the foetus, external examination findings, anthropometric measurements, internal examination findings, findings of the examination of head \& neck, brain and spinal cord, results of examination of placenta and umbilical cord were retrieved from the departmental achieves and analysed.

Cunningham \& Hollier classification ${ }^{[5]}$ was used to divide cases into foetal, placental or maternal categories as: Foetal (25-40\%) - chromosomal anomalies, non-chromosomal birth defects, non-immune hydrops, infections; Placental (25-35\%) - abruption, foetal-maternal haemorrhage, cord accident, placental insufficiency, intra partum asphyxia, placenta previa, twin to twin transfusion, chorioamnionitis; Maternal (5-10\%) - diabetes, hypertensive disorders, trauma, abnormal labour, sepsis, uterine rupture, postterm pregnancy, drugs, antiphospholipid antibodies, unexplained. 


\section{Result}

Over a period of four years from 2011 to 2015 , twenty eight cases of foetal autopsies were performed in the department of pathology. Mean maternal age was 25.3 years, youngest was 20 years and oldest was 36 years. Mode of delivery in almost all cases (27 cases) was vaginal and only one case was lower segment caesarean section (LSCS). Among 28 cases, eleven were therapeutic terminations, sixteen were intra-uterine deaths and one was perinatal death. We received twenty male foetuses and eight female foetuses and hence the male: female ratio was 2.5:1 in our series.

Most of the foetal deaths in our study, fourteen cases $(50 \%)$ were early foetal deaths, twelve cases $(42.9 \%)$ were intermediate and two were late foetal deaths (7.1\%). The number of cases in various categories and causes of foetal death have been shown in table 1 . The most prevalent cause of death was congenital anomalies (11 cases, 39.3\%) followed by placental insufficiency ( 5 cases, $17.8 \%$ ), Umbilical cord anomaly (3 cases, 10.7\%). Foetal causes were implicated in highest number of cases (46.5\%).

Congenital anomalies were common between gestational ages of 18-26 weeks. Birth weights ranging between 250-1000grams $(67.8 \%)$ were showing most congenital anomalies. The most common congenital anomaly detected was central nervous system and musculoskeletal system. The various anomalies detected according to the different systems are shown in table2.
We observed seven interesting cases including: Meckel Gruber syndrome, Arnold chiari malformation type 2, Double outlet right ventricle with ventricular septal defect, Twin - twin transfusion syndrome, Cystic hygroma, Gastrochisis and a case of floppy infant.

Placental insufficiency was the most common placental abnormality observed and umbilical cord anomalies with single artery were seen in three cases.

Anemia was the commonest maternal cause associated with congenital anomalies, followed by preeclampsia, polyhydromnios, oligohydrmonis and one case was positive for CMV. In one case, the mother was a known case of Hemophilia with history of losing the first baby and this foetus was the second conception. However, chorionc villus biopsy done at 16 weeks showed the foetus is not a case of haemophilia. The two cases with chorioamnionitis gave history of premature rupture of membranes.

Routine antenatal checkup included ultrasonography, and the reports were retrieved from the archives and analysed. There was a good correlation between the ultrasound findings and autopsy findings.

The different morphologic findings including the various gross abnormalities and the microscopic findings in the placenta, cord and foetuses that were seen at autopsy are shown in the table 3 .

Table 1: Distribution of cases in various categories and causes of foetal death.

\begin{tabular}{|l|c|c|c|}
\hline Categories & Causes & No. of cases & Percentage (\%) \\
\hline \multirow{4}{*}{ Foetal (46.5\%) } & Congenital Anomalies & 11 & 39.3 \\
\cline { 2 - 4 } & Infection & 1 & 3.6 \\
\cline { 2 - 4 } & Non - immune hydrops & 1 & 3.6 \\
\hline \multirow{4}{*}{ Placental (39.2\%) } & Twin to twin transfusion & 1 & 3.6 \\
\cline { 2 - 4 } & Placental Insufficiency & 5 & 17.8 \\
\cline { 2 - 4 } & Chorioamnionitis & 2 & 7.1 \\
\cline { 2 - 4 } Maternal (14.3\%) & Umbilical cord anomaly & 3 & 10.7 \\
\cline { 2 - 4 } & Diabetes & 1 & 3.6 \\
\hline Total & Pre-eclampsia & 1 & 7.1 \\
& Hypertension & 1 & $\mathbf{2 8}$ \\
\hline
\end{tabular}

Table 2: System wise distribution of congenital anomalies.

\begin{tabular}{|l|c|}
\hline Defects & No of cases ( total 11 cases) \\
\hline & Central nervous defects \\
\hline Spina bifida with Meningomyelocoele & 1 \\
Spina bifida with Rachischisis & 1 \\
Arnold chiari malformation & 1 \\
\hline
\end{tabular}




\begin{tabular}{|c|c|}
\hline Defects & No of cases ( total 11 cases) \\
\hline \multicolumn{2}{|c|}{ Musculoskeletal defects } \\
\hline $\begin{array}{l}\text { Gastrochisis } \\
\text { Unspecified }\end{array}$ & $\begin{array}{l}1 \\
1\end{array}$ \\
\hline \multicolumn{2}{|l|}{ Urogenital defects } \\
\hline Bilateral dysplastic kidneys & 1 \\
\hline \multicolumn{2}{|c|}{ Cardiovascular system defect } \\
\hline Double outlet right ventricle with ventricular septal defect & 1 \\
\hline \multicolumn{2}{|c|}{$\begin{array}{ll}\text { Lymphatic system defects } \\
\end{array}$} \\
\hline Cystic hygroma & 1 \\
\hline \multicolumn{2}{|l|}{ Multiple system defects } \\
\hline $\begin{array}{l}\text { Polydactyly, Occipital meningocoele, Bilateral dysplastic } \\
\text { kidneys, Hypoplastic lungs (Meckel-gruber syndrome) } \\
\text { Diaphragmatic hernia with spina bifida } \\
\text { Anencephaly +Facial abnormalities+ polydactyly }\end{array}$ & $\begin{array}{l}1 \\
1 \\
1\end{array}$ \\
\hline
\end{tabular}

Table 3: Morphological features in foetus, placenta and umbilical cord on autopsy.

\begin{tabular}{|c|c|c|c|}
\hline S.No & $\begin{array}{l}\text { Cause of foetal } \\
\text { death }\end{array}$ & Morphologic findings in foetuses in autopsy & $\begin{array}{l}\text { Morphologic findings in cord and } \\
\text { placenta in autopsy }\end{array}$ \\
\hline \multirow[t]{5}{*}{1.} & $\begin{array}{l}\text { Congenital } \\
\text { anomalies } \\
\text { (11 cases) }\end{array}$ & $\begin{array}{l}\text { Bilateral dysplastic kidneys } \\
\text { Gross: External and cut surface showed multiple thin } \\
\text { walled cysts involving the whole parenchyma (Figure 1A) } \\
\text { Micros: Immature tubules lined by a single layer of } \\
\text { cuboidal epithelium and surrounded by immature } \\
\text { mesenchyme. Many cystic spaces lined by cuboidal cells } \\
\text { and few scattered glomeruli were seen. (Figure 1B) }\end{array}$ & $\begin{array}{l}\text { Gross: Cord, placenta and } \\
\text { membranes were normal } \\
\text { Micros: The Placenta, cord and } \\
\text { membranes showed no significant } \\
\text { pathology. }\end{array}$ \\
\hline & & $\begin{array}{l}\text { Diaphragmatic hernia with spina bifida } \\
\text { Gross: Spina bifida with exposure of spinal cord starting } \\
\text { from mid thoracic to lumbar region. Left lobe liver, } \\
\text { stomach, proximal intestine and spleen were seen to } \\
\text { herniate into the left thorax with displacement of thoracic } \\
\text { structures in to right side. Left lung is hypoplastic } \\
\text { (Figure 2) } \\
\text { Micros: All organs were within normal limits. }\end{array}$ & $\begin{array}{l}\text { Gross: Cord, placenta and } \\
\text { membranes were normal. } \\
\text { Micros: Placenta showed features of } \\
\text { mild insufficiency with focal areas of } \\
\text { calcification }\end{array}$ \\
\hline & & $\begin{array}{l}\text { Meckel Gruber syndrome } \\
\text { Gross: Occipital meningocele (Figure 3A), Bilateral } \\
\text { dysplastic kidneys, Marked oligohydrominios, Polydactyly } \\
\text { in all four limbs (Figure 3B, 3C) and Hypoplastic lungs. } \\
\text { Micros: Sections from lungs were normal, sections from } \\
\text { kidney showed primitive glomeruli and primitive tubules } \\
\text { with dilated tubules lined by flattened cells and surrounded } \\
\text { by immature mesenchyme. Many cystic spaces lined by } \\
\text { cuboidal cells were noted. }\end{array}$ & $\begin{array}{l}\text { Gross: Placenta showed marginal } \\
\text { insertion of cord } \\
\text { Micros: Areas of infarction and focal } \\
\text { areas of chorangiosis } \\
\end{array}$ \\
\hline & & $\begin{array}{l}\text { Anencephaly with facial abnormalities and polydactyly } \\
\text { Gross: Absence of cranium with exposure of brain } \\
\text { substance. Occiput was bifid with a central defect. Low } \\
\text { set ears, cleft lip and cleft palate were noted. All four limbs } \\
\text { showed polydactyly. } \\
\text { Micros: All organs were within normal limits. }\end{array}$ & $\begin{array}{l}\text { Gross: Cord, placenta and } \\
\text { membranes were normal. } \\
\text { Micros: Placenta showed features of } \\
\text { mild insufficiency with focal areas of } \\
\text { calcification }\end{array}$ \\
\hline & & $\begin{array}{l}\text { Spina bifida with Rachischisis } \\
\text { Gross: Spine showed spina bifida and rachischisis from } \\
\text { D10 level to S1 level with absence of posterior spinal } \\
\text { elements (Figure 4A). } \\
\text { Micros: All organs were within normal limits. }\end{array}$ & $\begin{array}{l}\text { Gross: Cord, placenta and } \\
\text { membranes were normal. } \\
\text { Micros: Placenta showed focal areas } \\
\text { of necrosis and calcification } \\
\text { (Figure 4B). }\end{array}$ \\
\hline
\end{tabular}




\begin{tabular}{|c|c|c|c|}
\hline \multirow[t]{2}{*}{ S.No } & $\begin{array}{l}\text { Cause of foetal } \\
\text { death }\end{array}$ & Morphologic findings in foetuses in autopsy & $\begin{array}{l}\text { Morphologic findings in cord and } \\
\text { placenta in autopsy }\end{array}$ \\
\hline & & $\begin{array}{l}\text { Gastrochisis } \\
\text { Gross: Anterior abdominal wall showed a midline defect } \\
\text { with intestines protruding through the opening (Figure 5). } \\
\text { Micros: All organs were within normal limits. }\end{array}$ & $\begin{array}{l}\text { Gross: Placenta was bigger in size } \\
\text { and weight for the gestational age } \\
\text { (Figure 5). } \\
\text { Micros: Placenta showed features of } \\
\text { mild insufficiency. }\end{array}$ \\
\hline & & $\begin{array}{l}\text { Arnold chiari malformation - Type } 2 \\
\text { Gross: } \\
\text { Cerebellar tonsils were seen herniating through the } \\
\text { foramen magnum (Figure 6A). Spina bifida was seen in } \\
\text { the Lumbosacral region with meningo myelocoele. } \\
\text { Micros: All organs were within normal limits. }\end{array}$ & $\begin{array}{l}\text { Gross: } \\
\text { Cord, placenta and membranes were } \\
\text { normal } \\
\text { Micros: } \\
\text { The Placenta, cord and membranes } \\
\text { showed no significant pathology. }\end{array}$ \\
\hline & & $\begin{array}{l}\text { Double outlet right ventricle with ventricular septal } \\
\text { defect } \\
\text { Gross: Heart - right ventricle showed both opening of } \\
\text { aorta, pulmonary artery and a ventricular septal defect } \\
\text { was noted.(Figure 7) } \\
\text { Micros: All organs were within normal limits. }\end{array}$ & $\begin{array}{l}\text { Gross: Cord showed Single umbilical } \\
\text { artery } \\
\text { Micro: Cord showed Single umbilical } \\
\text { artery }\end{array}$ \\
\hline & & $\begin{array}{l}\text { Cystic hygroma with Hydrops fetalis- } \\
\text { Gross: Nuchal odema was seen. Whole foetus was } \\
\text { oedematous (Hydrops fetalis). A large sac measuring } \\
8 \text { 86cms was seen attached to the posterior aspect of neck } \\
\text { and filled with clear fluid. The lining of the cyst was smooth } \\
\text { and was filled with clear colourless fluid. (Figure } 8 \text { ) }\end{array}$ & $\begin{array}{l}\text { Gross: Cord, placenta and } \\
\text { membranes were normal } \\
\text { Micros: The Placenta, cord and } \\
\text { membranes showed no significant } \\
\text { pathology. }\end{array}$ \\
\hline & & $\begin{array}{l}\text { Spina bifida with Meningomyelocoele } \\
\text { Gross: Spina bifida was seen in the Lumbosacral region } \\
\text { with meningo myelocoele (Figure 9A). } \\
\text { Micros: All organs were within normal limits. }\end{array}$ & $\begin{array}{l}\text { Gross: Cord, placenta and } \\
\text { membranes were normal } \\
\text { Micros: Placenta showing features } \\
\text { of vascular insufficiency mainly } \\
\text { chorangiosis (Figure 9B, 9C). }\end{array}$ \\
\hline & & $\begin{array}{l}\text { Unexplained - } \\
\text { Gross: The foetus was floppy. No other abnormalities } \\
\text { were made out. } \\
\text { Micros: Sections from the skeletal muscle showed } \\
\text { features of pan fascicular atrophy. However tissue sent } \\
\text { for electron microscopy to a referral centre failed to any } \\
\text { specific findings. }\end{array}$ & $\begin{array}{l}\text { Gross: Cord, placenta and } \\
\text { membranes were normal } \\
\text { Micros: The Placenta, cord and } \\
\text { membranes showed no significant } \\
\text { pathology. }\end{array}$ \\
\hline 2. & Infection & $\begin{array}{l}\text { Gross: } \\
\text { All the organs were unremarkable Micros: Parenchymal } \\
\text { organs showed heavy interstitial mononuclear } \\
\text { lymphoplasmacytic infiltrates. }\end{array}$ & $\begin{array}{l}\text { Gross: Cord, placenta and } \\
\text { membranes were normal } \\
\text { Micros: Cord showed mild focal } \\
\text { mononuclear inflammation. Placenta } \\
\text { showed intervillious lympho } \\
\text { plasmacytic infiltrates. }\end{array}$ \\
\hline 3. & $\begin{array}{l}\text { Non - immune } \\
\text { hydrops }\end{array}$ & $\begin{array}{l}\text { Gross: Nuchal odema was seen. Whole foetus was } \\
\text { oedematous (Hydrops fetalis). } \\
\text { Micros: All organs were within normal limits. }\end{array}$ & $\begin{array}{l}\text { Gross: Cord, placenta and } \\
\text { membranes were normal } \\
\text { Micros: The Placenta, cord and } \\
\text { membranes showed no significant } \\
\text { pathology. }\end{array}$ \\
\hline 4. & $\begin{array}{l}\text { Twin to twin } \\
\text { transfusion } \\
\text { syndrome }\end{array}$ & $\begin{array}{l}\text { Gross: One foetus was congested and plethoric and the } \\
\text { other was pale and anaemic (Figure } 10 \text { ) } \\
\text { Micros: All organs were within normal limits. }\end{array}$ & $\begin{array}{l}\text { Gross: Cord, placenta and } \\
\text { membranes were normal } \\
\text { Micros: Placenta was monoamnionic } \\
\text { and monochorionic with features of } \\
\text { mild insufficiency. }\end{array}$ \\
\hline
\end{tabular}




\begin{tabular}{|c|c|c|c|}
\hline S.No & $\begin{array}{l}\text { Cause of foetal } \\
\text { death }\end{array}$ & Morphologic findings in foetuses in autopsy & $\begin{array}{l}\text { Morphologic findings in cord and } \\
\text { placenta in autopsy }\end{array}$ \\
\hline 5. & $\begin{array}{l}\text { Placental } \\
\text { Insufficiency } \\
\text { (5 cases) }\end{array}$ & $\begin{array}{l}\text { Gross: Features of Intra Uterine Growth Retardation } \\
\text { Micros: All organs were within normal limits. }\end{array}$ & $\begin{array}{l}\text { Gross: Cord, placenta and } \\
\text { membranes were normal } \\
\text { Micros: Increased syncytial knots, } \\
\text { increase in terminal mature villi, } \\
\text { decreased vasculature, areas of } \\
\text { infarction, necrosis and fibrosis, foci } \\
\text { of dystrophic calcification.(Figure 11) }\end{array}$ \\
\hline 6. & $\begin{array}{l}\text { Chorioamnionitis } \\
(2 \text { cases })\end{array}$ & $\begin{array}{l}\text { Gross: } \\
\text { All organs were normal } \\
\text { Micros: } \\
\text { All parenchymal organs were normal except for a mild } \\
\text { mononuclear inflammatory infiltrates in interstial spaces of } \\
\text { the lung. }\end{array}$ & $\begin{array}{l}\text { Gross: Placenta showed focal areas } \\
\text { of infarction and fibrinous deposits. } \\
\text { Micros: Presence of areas of fibrinoid } \\
\text { necrosis and neutrophilic infiltrates } \\
\text { in the amnion, chorionic plate and } \\
\text { decidua (Figure 12). Some of the villi } \\
\text { also showed neutrophilic infiltrates. }\end{array}$ \\
\hline 7. & $\begin{array}{l}\text { Umbilical cord } \\
\text { anomaly } \\
\text { ( } 3 \text { cases) }\end{array}$ & $\begin{array}{l}\text { Gross: No abnormality detected } \\
\text { Micros: All the organs were within normal limits. }\end{array}$ & $\begin{array}{l}\text { Gross: Two cases had single } \\
\text { umbilical artery and more case had } \\
\text { true knots in the cord. Micros: single } \\
\text { umbilical artery was noted. }\end{array}$ \\
\hline 8. & $\begin{array}{l}\text { Maternal } \\
\text { Diabetes mellitus }\end{array}$ & $\begin{array}{l}\text { Gross: No abnormality detected } \\
\text { Micros: All the organs were within normal limits. }\end{array}$ & $\begin{array}{l}\text { Gross: Cord, placenta and } \\
\text { membranes were normal } \\
\text { Micros: Placenta showing features } \\
\text { of vascular insufficiency mainly } \\
\text { chorangiosis. }\end{array}$ \\
\hline 9. & $\begin{array}{l}\text { Maternal Pre- } \\
\text { eclampsia } \\
(1 \text { case) } \\
\text { Pregnancy induced } \\
\text { hypertension } \\
(1 \text { case) }\end{array}$ & $\begin{array}{l}\text { Gross: Foetus showed features if IUGR. } \\
\text { Micros: All organs were unremarkable. }\end{array}$ & $\begin{array}{l}\text { Gross: Cord, placenta and } \\
\text { membranes were normal } \\
\text { Micros: Placenta showing features of } \\
\text { vascular insufficiency mainly infarct, } \\
\text { calcification and chorangiosis }\end{array}$ \\
\hline 10. & $\begin{array}{l}\text { Maternal } \\
\text { Haemophilia }\end{array}$ & $\begin{array}{l}\text { Gross: No abnormality detected } \\
\text { Micros: All the organs were within normal limits. }\end{array}$ & $\begin{array}{l}\text { Gross: Cord, placenta and } \\
\text { membranes were normal } \\
\text { Micros: Placenta showing features } \\
\text { of insufficiency including, increased } \\
\text { syncytial knots, increase in terminal } \\
\text { mature villi, decreased vasculature, } \\
\text { areas of infarction, necrosis and } \\
\text { fibrosis, foci of dystrophic calcification. }\end{array}$ \\
\hline
\end{tabular}

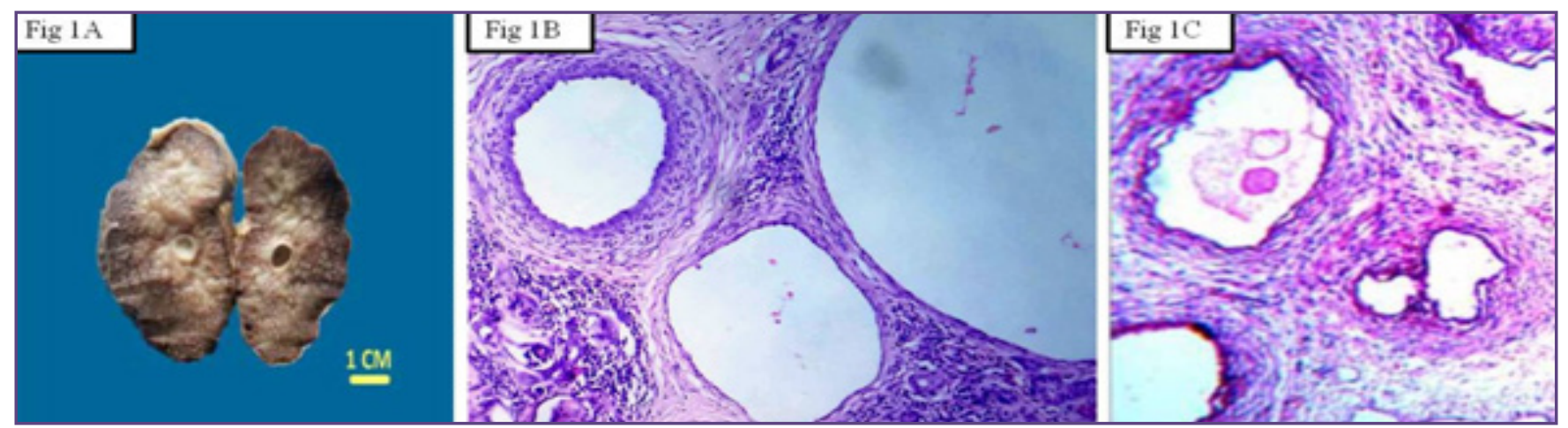

Fig. 1: Bilateral dysplastic kidneys. A -Gross image showing cut surface with multiple thin walled cysts, involving the whole parenchyma. B - microscopic picture showing renal tissue with immature tubules surrounded by immature mesenchyme and cystic spaces with few scattered glomeruli (H\&E 40X). C - microscopic picture showing dilated tubules lined by single layer of cuboidal epithelium with surrounding by immature mesenchyme (H\&E 100X). 


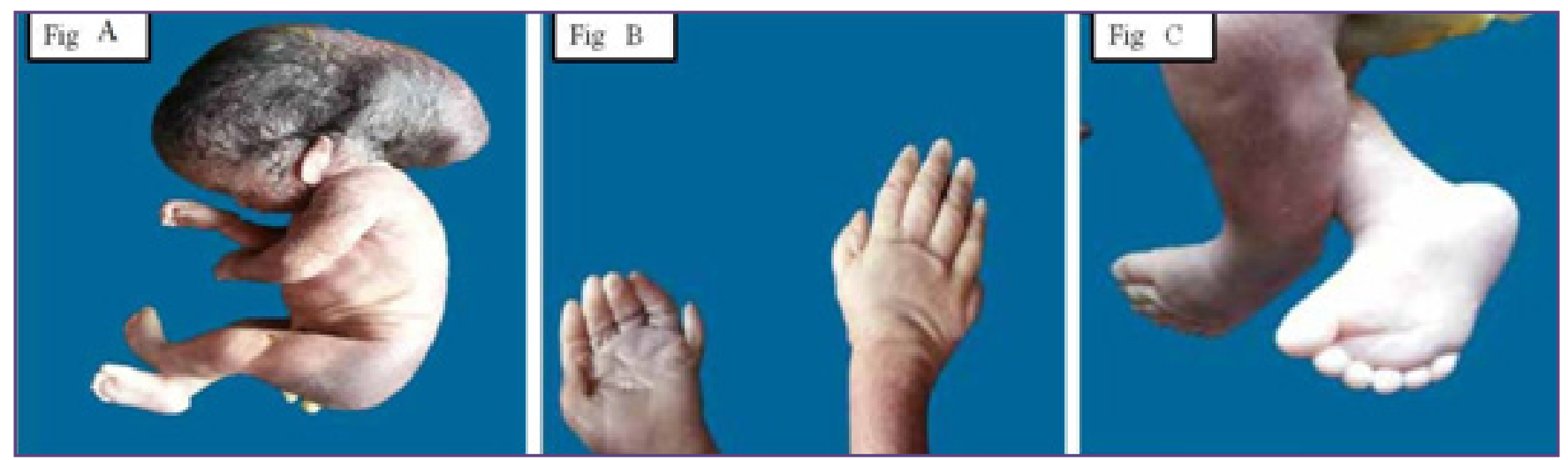

Fig. 2: Meckel Gruber syndrome. A- Gross image showing meningocele. B-Gross image showing polydactyly (Six digits) in upper limbs. C- Gross image showing polydactyly (Six digits) in lower limbs.

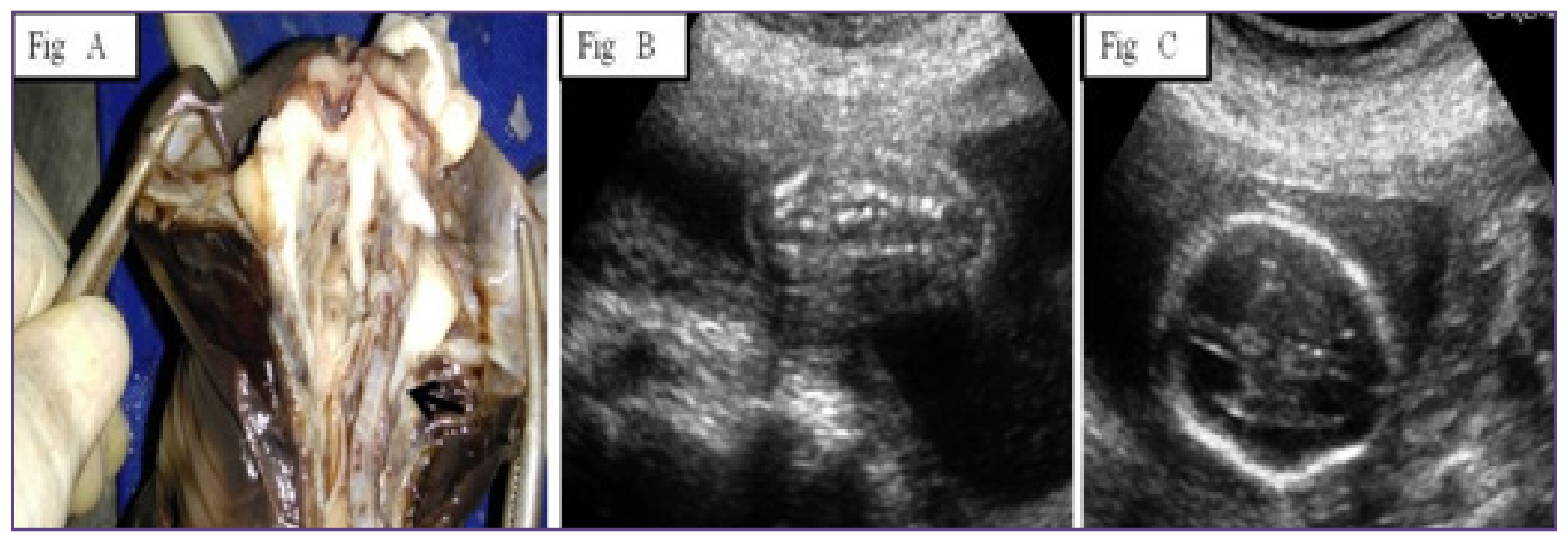

Fig. 3: Arnold chiari malformation -Type 2. A - Gross image showing the herniation of cerebellar tonsils through the foramen magnum upto upper cervical vertebra (arrows). B - Ultrasound image demonstrating banana sign. C - Ultrasound image demonstrating lemon sign.

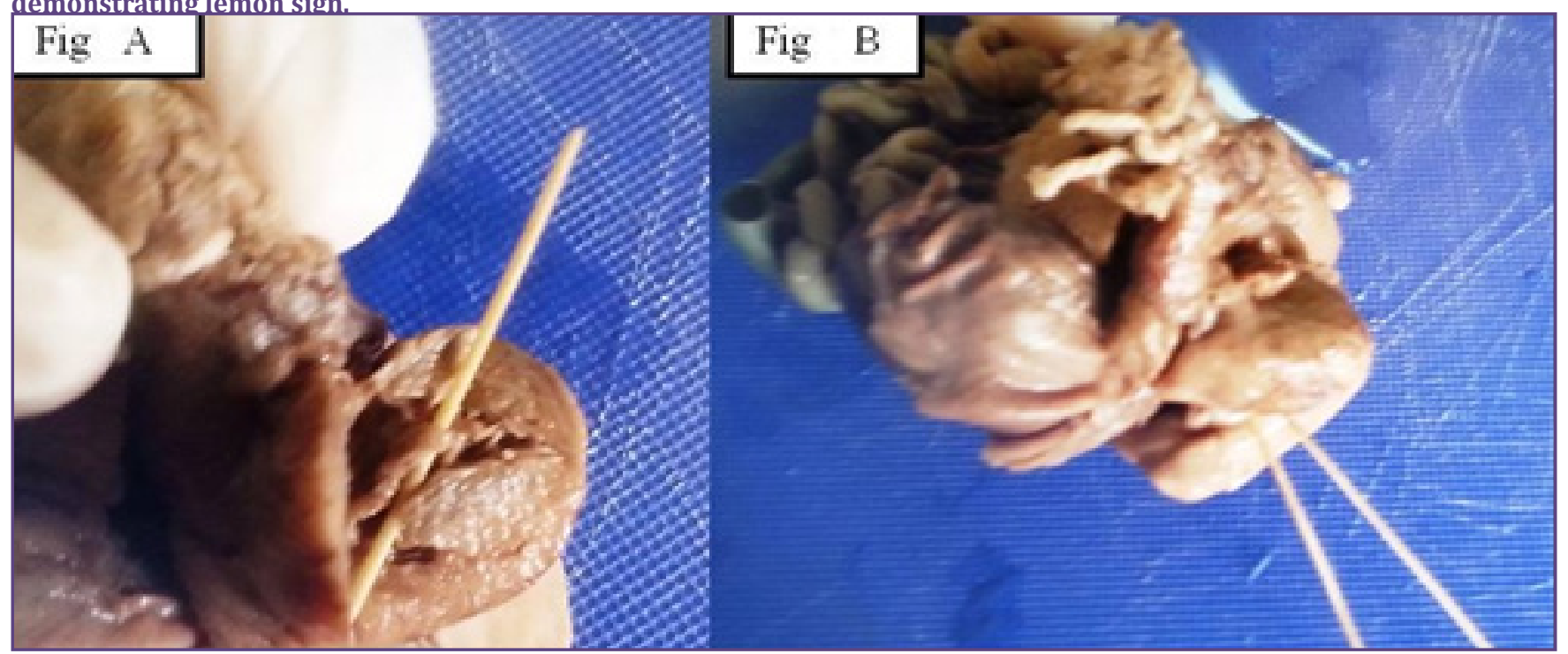

Fig. 4: Double outlet right ventricle withventricular septal defect. A - Gross image showing communication between the two ventricles. B - Gross image showing opening of both aorta and pulmonary artery into right ventricle as pointed by the two sticks. 


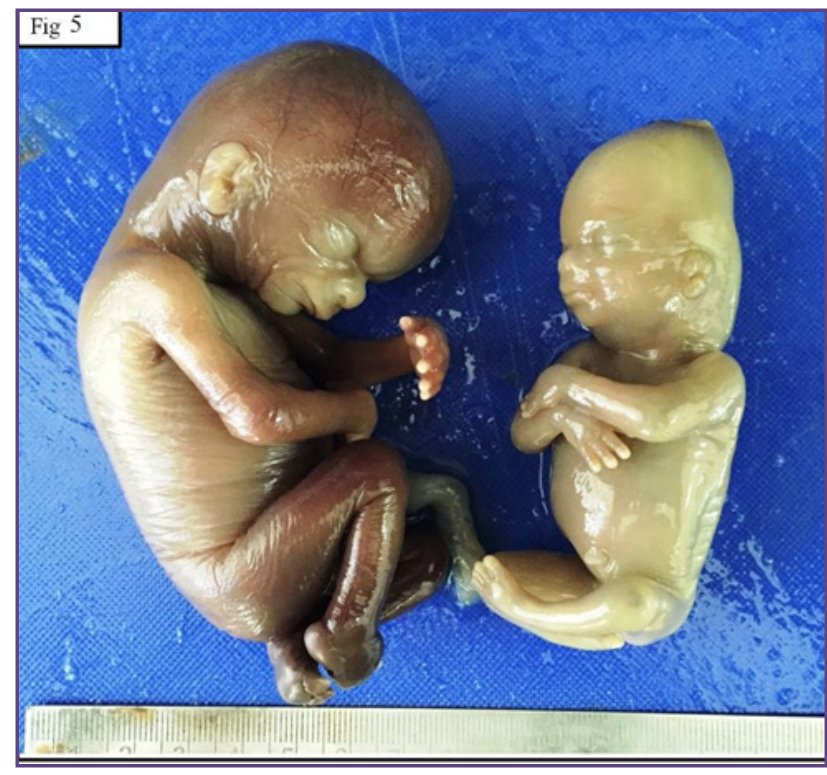

Fig. 5: Twin -twin transfusion syndrome. Gross image showing one foetus, congested and plethoric and the other foetus, pale and anaemic.

\section{Discussion}

Foetal autopsy contributes a lot to the diagnosis of IUD and congenital anomalies are a most important cause of perinatal deaths. If performed meticulously along with detailed history from clinician, the foetal autopsies can identify the cause of foetal death in most of the cases. In a study by Faye Petersen et al. the cause of death could be detected by autopsy in $94 \%$ of the cases. ${ }^{[6]}$

In developing countries like India, congenital malformations remain an important cause and contribute to 25 to $30 \%$ cases of perinatal death. ${ }^{[7]}$ Major congenital anomalies were seen in 3\% of neonates. Multiple congenital anomalies with risk of recurrence in the subsequent pregnancies were noted in $0.7 \%$ of the neonates. ${ }^{[7]}$ In our study also congenital anomalies was the leading cause and accounted for about $39.3 \%$ of the cases and multiple anomalies were found in $10.7 \%$, which is much higher than in literature, probably because of regional variations and increased prevalence of consanguinity in our region.

In their study, Faye Petersen et al. also detected that one third of the foetal deaths were caused by congenital structural anomalies of which the most common ones were the neural tube defects, hydrops foetalis and congenital heart diseases. ${ }^{[6]}$ Neural tube defects had a five percent risk of recurrence in subsequent pregnancies. ${ }^{[7]} \mathrm{In}$ one of our case where the foetus was diagnosed to have spina bifida and meningomyelocoele, also had a history of previous sibling with spina bifida.
The most common congenital anomalies were Central nervous system (CNS) disorders accounting for $20-45 \%$. Nielson et al. reported $34.8 \%$ in 2006, ${ }^{[8]}$ Ceylaner et al. reported $26.4 \%$ in $2007,{ }^{[9]}$ Tomatir et al reported $31.1 \%$ in $2009^{[10]}$ and Andola et al. reported $34.09 \%$ in 2013. ${ }^{[9]}$ Our current study shows $21.4 \%$. We had a case of Arnold chiari malformation type II.

In the series of Tuncbilek $\mathrm{E}$ et al, the most frequent congenital malformations were those in the musculoskeletal system. ${ }^{[1]}$ On the other hand; malformations of the musculoskeletal system were the second most common in our series. One case was diagnosed by ultrasonography and confirmed by autopsy. But the other case was diagnosed only by autopsy.

About $25-35 \%$ of the foetal deaths were due to the abnormalities in the cord, Placenta and membranes. ${ }^{[12]}$ Anomalous foetuses also had abnormal findings in the placenta. The main abnormalities in placenta included placental infection and placental insufficiency, which was associated with intra uterine growth retardation. ${ }^{[13]}$ Soma et al. Identified that the most common lesion found in pregnancy induced hypertension (PIH) and pre eclampsia was placental infarction $(54.7 \%),{ }^{[14]}$ which was also supported by the study of Wentworth, who identified placental infarction in placenta of $67 \%$ of women with severe PIH and in $11.7 \%$ of women with mild PIH. ${ }^{[15]}$ In our study, placental causes per sae, accounted for $39.2 \%$ of foetal deaths and there were placental abnormalities in addition to congenital malformations in $21.4 \%$ of foetuses.

The most common abnormality in placenta in our study was placental insufficiency. The features of placental insufficiency include increase in syncytial knots also referred to as the Tenny-Parker change. It is termed as increase in syncytial knots, when more than thirty percent of the tertiary villi possess syncytial buds. ${ }^{[16]}$ Another finding is in insufficiency are calcifications and literature states that this placental finding is associated with foetal distress.

Bengston et al. documented chorioamnionitis in $45.8 \%$ of cases with premature rupture of membranes. And out of this $49.1 \%$ foetuses died thus had perinatal mortality indicating that the chorioamnionitis is an important cause of intrauterine death. Premature rupture of membranes and pre term labour is the most common cause of amnionitis. [17] In our study chorioaminiotis was seen in two cases, both had history of premature rupture of membranes. Nonspecific mild inflammation was also seen in one case. It's well documented that infection is one of the important causes of neonatal deaths and still births. Cytomegalovirus 
(CMV) infection was seen in one case and serological test was positive in the mother. CMV infection is one of the important causes of chronic villitis and is characterised by chronic mononuclear cell infiltrate. ${ }^{[17]}$

Maternal causes contribute only to a small proportion of foetal deaths, for the reason that maternal factors in addition have foetal or placental causes. And these additional foetal and placental causes were attributed to cause foetal death, rather than the maternal factors. The two most common maternal causes of still births are diabetes mellitus and hypertensive disorders, accounting for about five to eight percentage. ${ }^{[12]}$ Diabetes mother usually have foetuses with congenital anomalies and hypertensive mothers have placental infarction and other features of placental insufficiency. Maternal causes were responsible for $14.3 \%$ of foetal deaths in our study. The diabetic, hypertensive and haemophiliac mothers in our study had abnormal findings in placenta as well.

Other causes of foetal death like infection, trauma and cord accident do not have risk of recurrence in future pregnancies. Cord abnormalities were the third most common cause of foetal deaths in our study accounting for about $10.7 \%$. Some causes of congenital anomalies like to exposure to a teratogen or uncontrolled glycaemic levels can be prevented in future pregnancies. The most common disorders with risk of recurrence include maternal factors like diabetes mellitus and hypertension which can be avoided by proper pre conceptional care and antenatal interventions.

Routine screening by prenatal ultrasound is likely to detect major congenital anomalies and even though detection rates may differ, most of the severe foetal anomalies are documented prenatally. ${ }^{[18]}$ However, additional findings which may indicate the possibility of recurrence in subsequent pregnancies can be detected with foetal autopsy and can be helpful to counsel the parents. Literature data shows that the autopsy examination gave additional findings that were not diagnosed by prenatal ultrasound examination and added importantly about the chance of recurrence, and thus plays a crucial role in counselling the parents.

\section{Conclusion}

To conclude, Foetal autopsy is a vital procedure in confirming the cause of foetal death and thus plays a crucial role in prenatal workup. It also provides additional findings not identified through prenatal ultrasound, which can modify the cause of death and thus the risk of recurrence in subsequent conceptions. It is an important tool in providing the treating clinician and parents with very crucial information on implications for future pregnancies.

\section{Acknowledgements}

I deeply acknowledge my Professor and HOD with all technical staff of department of pathology for helping out in the processing and writing up of this article.

I also acknowledge the department of obstetrics for providing the fetuses for conducting of fetal autopsies to help in the diagnosis of causes of fetal demise.

\section{Reference}

1. Fatima U, Sherwani R, Khan T, Zaheer S: Foetal AutopsyCategories and Causes of Death. J Clin Diagn Res 2014; 8:FC05-08

2. Ceylaner G, Ceylaner S, Gunyeli I, Ekici E, Celasun B, Danıșman N: Evaluation of 2407 fetuses in a Turkish population. Prenat Diagn 2007; 27: 800-7.

3. Brodie M, Laing IA, Keeling JW, Meckenzie KJ: Ten years of neonatal autopsies in tertiary referral centre: retrospective study. BMJ 2002; 324:761-3.

4. Siebert JR: Perinatal, fetal and embryonic autopsy: in Gilbert-Barness E, Kapur RP, Oligny LL, Siebert JR, eds. Potter's pathology of the fetus, infant, and child. Philadelphia: Mosby Elsevier; 2007, 685-729.

5. Cunninnham FG, Hollier LM: Fetal Death: in Cunninnham FG, Williams, Whitridge J, eds. Williams Obstetrics. Norwalk Ct: Appleteon \& Lange; 1997.

6. Faye-Petersen OM, Guinn DA, Wenstrom KD: The value of perinatal Autopsy. Obstel Gynecol 1999; 94:915-20.

7. Shankar VH, Phadke SR: Clinical utility of fetal autopsy and comparison with prenatal ultrasound findings. J Perinatol 2006; 26:224-29.

8. Nielsen LA, Maroun LL, Broholm H, Laursen H, Graem $\mathrm{N}$ : Neural tube defect and associated anomalies in a fetal perinatal autopsy series. APMIS 2006; 114:239-46.

9. Ceylaner S, Ceylaner G, Gunyeli I,Ekici E,Tug M, Taner D, Ekerbicer H, Mollamahmutoglu L, Danisman N: Postmortem evaluation of 220 prenataly diagnoses fetuses with neural tube defect detection of associated anomalies in a Turkish population. Prenat Diagn 2006; 26:147-53.

10. Nayak SR, Garg N: Determination of antepartum fetal death. J Obstet Gynecol India 2010; 60:494-7.

11. Tuncbilek E, Boduroglu K, Alikasifoglu M: Results of the Turkish congenital malformation survey. Turk J Pedi atr 1999; 41:287-97.

12. Allessandri LM, Stanley FJ, Garner JB, Newham J, Walters BNJ: A case-control study of unexplained antepartum stillbirths. Br J Obstet Gynecol 1992; 99:711-8.

13. Bonetti LR, Ferrari P, Trani N, Maccio L, Laura S, Giuliana S, Facchinetti F, Rivasi F: The role of fetal autopsy and 
placental examination in the causes of fetal death: a retrospective study of 132 cases of stillbirths. Arch Gynecol Obstet 2011; 283:231-41.

14. Soma H, Yoshida K, Mukaida T, Tabuchi Y: Morphologic changes in the hypertensive placenta. Contrib. Gynecol. Obstet 1982; 9:58-75.

15. Wentworth P: Placental infarction and Toxemia of pregnancy. Am J Obstet Gynecol 1967; 99:318-26.
16. Tenney B, Parker F: The placental in Toxemia of pregnancy. Am J Obstet Gynecol 1940; 39:1000-5.

17. Bengtson J.M, Van Marter LJ, Barss VA, Greene MF, Tuomala RE, Epstein MF: Pregnancy outcome after premature rupture of membranes at or before 26 weeks gestation. Obstet Gynaecol 1989; 73:921-7.

18. Grandjean H, Larroque D, Levi S: The performance of routine ultrasonographic screening of pregnancies in the Eurofetus study. Am J Obstet Gynaecol 1999; 81:446-54.

\section{*Corresponding author:}

Dr P Jayaganesh, Postal Address: No 47, Jani Jhan Khan Road, Royapettah, Chennai 600014 INDIA

Phone: +91 9884115987

Email: jayaganeshp@gmail.com

Financial or other Competing Interests: None. 